\title{
遺伝アルゴリズムとファジィ制御を用いた 合流式下水道ポンプ操作の高度化 ADVANCED PUMP OPERATION IN COMBINED SEWER SYSTEMS USING GENETIC ALGORITHMS AND FUZZY CONTROL
}

\author{
八木俊策 ${ }^{1} \cdot$ 芝 定孝 ${ }^{2}$ \\ Shunsaku YAGI and Sadataka SHIBA \\ 1 正会員 工博 摂南大学助教授 工学部経営工学科（勇572 大阪府寝屋川市池田中町17-8) \\ ${ }^{2}$ 正会員 工博 大阪大学助手 基礎工学部化学工学科（テ560 大阪府豊中市待兼山1-1）
}

\begin{abstract}
In the present study, fuzzy logic control and genetic algorithms are applied to achieve advanced pump operation in combined sewer systems. Pumping rates are determined by fuzzy inference and fuzzy control rules corresponding to input variables. Genetic algorithms are used to automatically improve the fuzzy control rules through the genetic procedures of selection, crossover, and mutation. The effects of different fitness functions and learning conditions are investigated using a stormwater runoff model.

Conclusively, it is found that current pump operation can be improved by adding sewer water quality to the input variables and the fitness function; the improved operation can reduce not only floods in the drainage area but also pollutant loads discharged to the receiving waters.
\end{abstract}

Key Words : fuzzy control, genetic algorithms, evolutional computation, pump operation combined sewer overflows, stormwater drainage

\section{1.はじめに}

都市化の進展にともなって、都市の水システムは 大規模化・複雑化・多目的化し、また観測・予測情 報も多量化・多様化しつつある. そのため種々の水 関連施設においては、より高度な制御が求められつ つあり、現場のオペレータに対する支援システムの 必要性が高まっている。一方、人間の行う知識情報 処理に関する研究から生された A I 技術は、体系的 に知識を集積・学習し、推論によって問題を解決す る、人間の知能の働きに近い機能をもつ計算機利用 システムである．狭義にはエキスパートシステムが その代表であるが、広義にはファジィ推論やニュー ラルネット、遺伝アルゴリズムなどをも含む形で発 展しつつある. 水システム関連分野ではダム貯水池 の操作や浄水場での凝集剂の注入制御などに適用さ れ、熟練オペレータの知識や経験をうまく取り入れ ることによって、人間に近い操作が実現しうるとさ れている.

雨天時に重要な役割をもつ合流式下水道ポンプ場 におけるオペレータのポンプ操作に関しては、従来 よりファジィ制御を用いた支援システムの検討が行

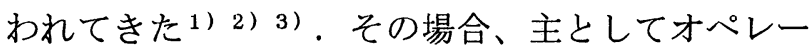

タへのインタビューなどに基づいて、発見的、試行 錯誤的にファジィ制御ルールが作成されてきた。し かしながら、オペレータの知識や経験を的確に制御 ルールとして把握することは容易でなく、さらに入 力変数や制御目的が増すにつれ、ルールの作成や更 新は極めて困難になってくるという問題があった。

そこで本研究では、遺伝アルゴリズムによってファ ジィ制御ルールを自動的に求める方法4）5）6）を適 用して、合流式卜水道ボンプ場における雨水・污水 ポンプ操作の高度化について検討した.

\section{2. 雨水污濁流出システムとポンプ場の概要}

雨天時における合流式下水道ポンプ場の役割は、 図一 1 に示すように放流先公共用水域の氾濫防止や 排出污濁負荷の軽減に留意しつつ、排水区域の浸水 を防止することにある. 面源污濁を含む降雨初期の 高污濁下水は、污水ポンプによって次のポンプ場ま たは下水処理場へ送られる. さらに流入流量が増加 して所定の希釈倍率を超えたり、降雨現況や予報か ら流入量の増加が予想されるときには雨水ポンプに より河川などへ放流される. 現場のオペレータは降 


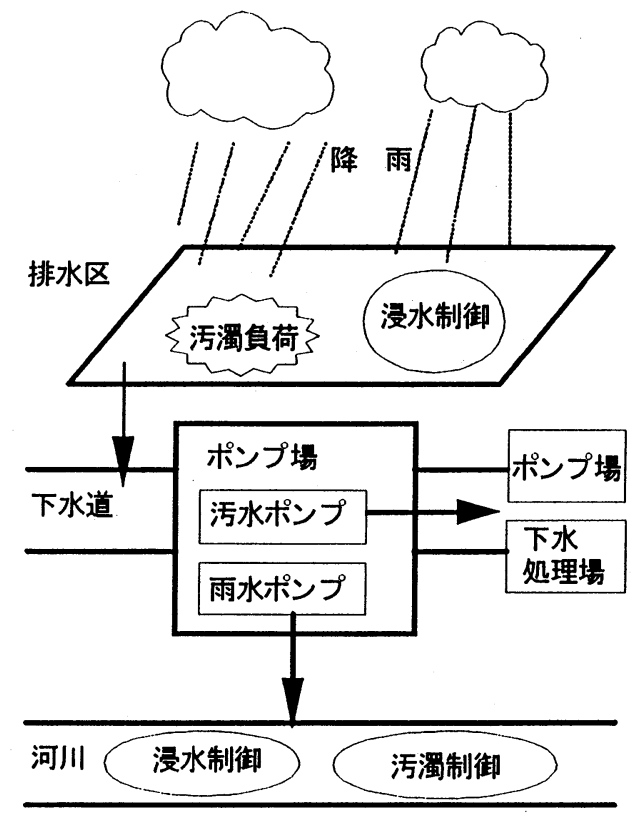

図ー1 雨水污濁流出システムとポンプ場

雨強度、下水管水位、放流先河川水位などの多入力 情報にもとづき、知識・経験・勘を活かしつつ、ポ ンプ操作量を決定している.

本研究ではポンプ場におけるオペレータの操作を ファジィ制御でモデル化し、また雨水污濁流出シス テムについては、大阪府下の合流式下水道排水区を 刘象として作成されたものを用いた ${ }^{1)}$ 。

\section{3. 雨水・污水ポンプのファジィ制御}

Zadehのファジィ集合7）を制御に応用したファジィ 制御は、定式化が難しくて古典的な制御法では取り 扱いにくいシステムの制御に適用され、熟練オペレー タに近い制御効果を示すことがすでに実証されてい

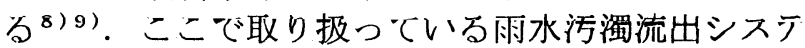
ムにおけるポンプ操作もそのような問題に含まれる と考える.

（1）入出力変数とメンバーシップ関数

入力変数は下水管水位（ゲート前水位）、降雨強

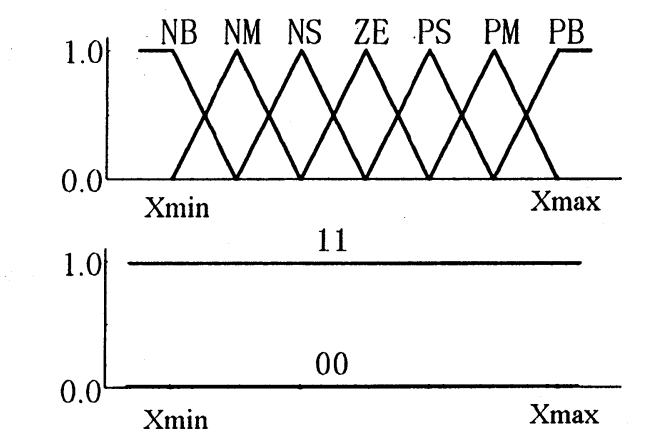

図ー2 ファジィラベルとメンバーシップ関数
度、放流先河川水位、下水水質であり、出力変数は 雨水ポンプ操作量および污水ポンプ操作量である. 本研究ではファジィラベルとしてNB、NM、NS、ZE、 PS、PM、PBおよび11、00の 9 個を用いた。これらの メンバーシップ関数を図ー2に示す. Xmin、Xmax はそれぞれ各変数の最小值および最大值である。こ こでは、降雨強度 $(0 \sim 50 \mathrm{~mm} / \mathrm{hr})$ 、下水管水位 $(0.5$ $\sim 5.0 \mathrm{~m})$ 、河川水位 $(0 \sim 3.0 \mathrm{~m})$ 、下水水質 $(0 \sim$ $\left.200 \mathrm{~g} / \mathrm{m}^{3}\right)$ としている. ラベル11はメンバーシップ值 が常に 1 であり、ラベル00は常に 0 の值を持つ. ラ ベル11は制御ルールの前件部 (IF . . . ) に、ラベル00 は後件部(THEN ....)に用いることができるようになっ ている。したがって、あるルールに $X 1=11$ が含 まれるとき、実質的には入力変数 $X 1$ ぞそのルールで は不必要であることを意味する. 同様に $Y=00$ は そのルールが無効であることを意味する.

\section{（2）ファジィ制御ルール}

「もし下水管水位 $(X 1)$ が高く、かつ降雨強度 (X2) が最大レベルのときには、ポンプ操作量 $(Y)$ を最大にする」とか「もし下水管水位が低く、かつ 雨が止んだときには、ポンプを止める」・・・といっ た言語的表現は、ファジィ制御ルールとして、次の ように表される.

$$
\begin{array}{lllll}
\text { IF } & X 1=P B & X 2=P B & \text { THEN } & Y=P B \\
\text { IF } & X 1=N B & X 2=N B & \text { THEN } & Y=N B
\end{array}
$$

\section{（3）ファジィ推論法}

ファジィ推論にはMin-Max-重心法を用いた。す なわち入力值に対する前件部の各ファジィ集合のメ ンバーシップ值の最小值を各ルールの適合度 (grade) とし、その值を後件部のメンバーシップ関 数に乗に゙、すべてのルールについてそれらの最大值 を用いて合成する。そして、このメンバーシップ関 数の重心を操作量とする方法である ${ }^{9)}$.

\section{4. 遺伝アルゴリズムによるファジィ制御ルー ルの自動生成}

遺伝アルゴリズム (Genetic Algorithm：GA) は、 生物の遺伝と進化にヒントをえた最適化や学習のた めの方法であり、種々の分野への応用が試みられて

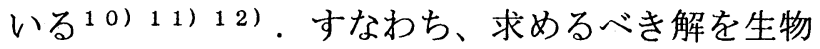
の遺伝子のようにコード化し、選択・交叉・突然変 異などの遺伝的操作によって、環境への適応度を高 めていく方法である.

\section{（1）ファジィ制御ルールの遺伝子表現}

遺伝子表現にはビットストリング表現がよく用い られるが、ここではファジィルールベースを構成す る各ルールのファジィラベルをそのまま鎖状に並べ 
た形で表現する．たとえばルールベース $R_{A}$ が次の

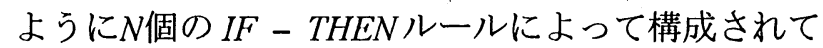
いる場合、

$$
\begin{gathered}
\text { 1: IF } X 1=P B X 2=P M \ldots . \text { THEN } Y=P B \\
2: \text { IF } X 1=N B X 2=N S \ldots \text { THEN } Y=N B \\
\text { ・ ・ ・ } \\
N: \text { IF } X 1=Z E X 2=P S \ldots \text { THEN } Y=Z E
\end{gathered}
$$

このルールベースの遺伝子列を次のように表現する

$$
\begin{aligned}
& R_{A}:(P B, P M, \ldots, P B)(N B, N S, \ldots, N B) \quad \ldots \\
& \begin{array}{lll}
A_{1} & A_{2} & \ldots
\end{array} \\
& (Z E, P S, \ldots, Z E) \\
& A_{N}
\end{aligned}
$$

\section{(2) 適応度}

ある個体が環境に適応する度合いを適応度 (fitness) という。ここでは、現行型と改良型それ ぞれのポンプ操作について表ー1に示すように与え

表 -1 入力変数と適応度 (現行型・改良型)

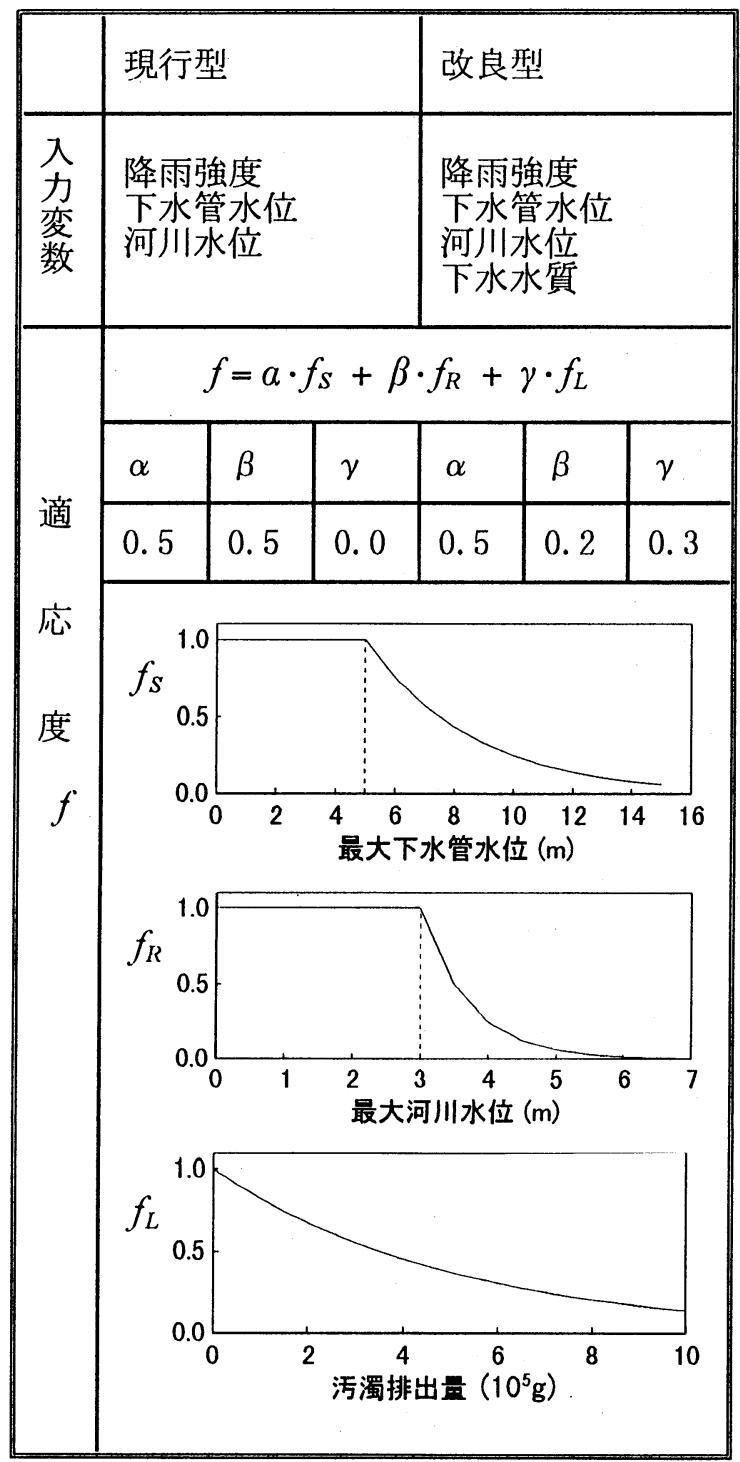

ている。 すなわち現行型のポンプ操作では、ある降 雨に対して最大下水管水位が $5 \mathrm{~m}$ 以下、最大河川水 位が $3 \mathrm{~m}$ 以下になるように操作された場合、適応度 が最大值 1.0 となるように定めている。一方、改良 型の場合、さらに適応度に污濁排出量を加えている ので、単に下水管水位や河川水位だけでなく、雨水 ポンプによる污濁排出量を低下させるような操作で なければ適応度を高めることはできない。

ただし、ここでいう現行型というのは必ずしも現 場の熟練オペレータの操作を意味しているのではな い.すなわち、現行のポンプ場において、通常、計 測されている入力情報にもとづく操作を現行型とし ている．実際、熟練オペレータはこれらの情報以外 にも、たとえば経験や勘にもとづく降雨予測や初期 污濁を考慮している.

\section{（3）遺伝オペレーション}

\section{a）選択}

ある世代の個体群の中から、適応度の高い個体を 選択して、次世代に残す操作である.ここではルー レット選択とエリート保存選択を用いた。ルーレッ 卜選択は集団のす心゙ての個体の適応度の合計に対す る、ある個体の適応度の比率を選択確率として、次 世代に残す方法である。またエリート保存選択は、 交叉や突然変異によって高い適応度をもつ個体（ルー ルベース）が壊されるのを防ぐため、ある世代にお いて最大の適応度をもつ個体をそのまま次世代に残 す遺伝戦略である。

\section{b) 交叉}

2 つの個体の遺伝子列を確率的に決定される位置 で切断し、相互に入れ替えて新たな遺伝子列を作る 操作である。交叉の方法には 1 点交叉、多点交叉、 一様交叉などの方法が提案されているが、ここでは 1 点交叉を用いる. 例えば交叉対象となるルールベー ス $R_{A}, R_{B}$ の 2 番目と 3 番目のルールの間に交叉位置 がある場合、次のようになる。

$$
\begin{aligned}
R_{A} & : A_{1} A_{2} \mid A_{3} A_{4} \ldots \ldots . A_{N} \\
R_{B} & : B_{1} B_{2} \mid B_{3} B_{4} \ldots \ldots . . B_{N} \\
& \Downarrow 1 \text { 点交叉 } \Downarrow \\
R_{A}^{\prime} & : A_{1} A_{2} B_{3} B_{4} \ldots \ldots . B_{N} \\
R_{B}^{\prime} & : B_{1} B_{2} A_{3} A_{4} \ldots \ldots . A_{N}
\end{aligned}
$$

ある個体（ルールベース）が 1 世代で交叉の対象 になる平均回数を交叉率とする. 本研究では 1.0 と している.

c）突然変異

ある遺伝子を確率的に対立遺伝子で置き換える操 作である.ルールベースにおいてい入出力変数の大 きさを表すファジィラベルを別のものに置き換える 操作である(例 : $X 2=P B \rightarrow X 2=P S$ ). ある遺伝 子が 1 世代において対立遺伝子に置き換えられる平 均回数を突然変異率とする. 本研究では 0.1 とした。 


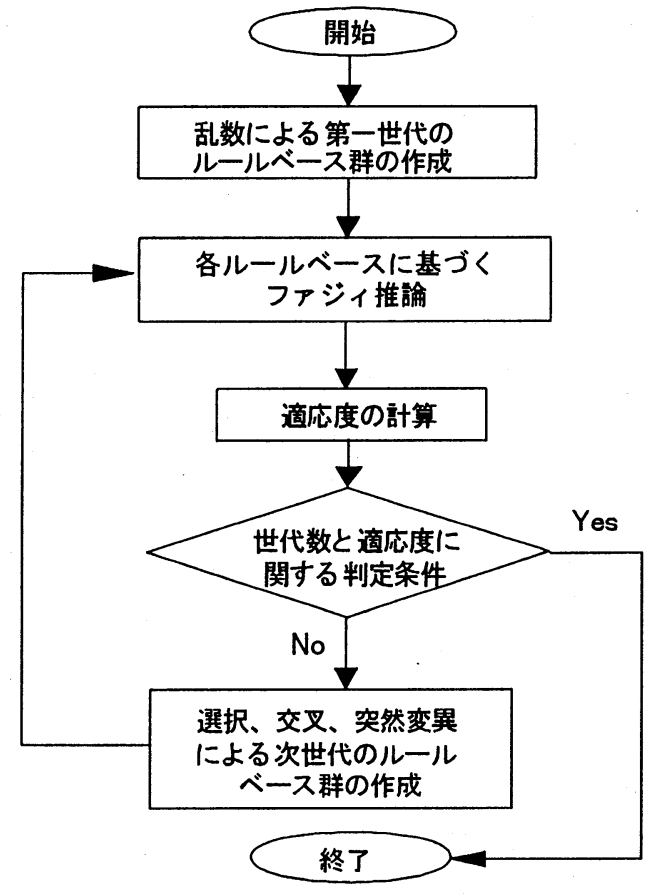

図ー3＼cjkstart遺伝アルゴリズムによる計算手順

\section{（4）遺伝アルゴリズムによる計算手順}

遺伝アルゴリズムを用いてファジィ制御ルールを 計算する手順を図ー ろに示す。 まず乱数によって第 1 世代の個体群、すなわちファジィルールベース群 を作成する，つぎにある降雨パターンに対して、雨 水污濁流出モデルを用いて、各ルールベースにもと づくポンプ操作を行い、最大下水管水位、最大河川 水位、污濁排出量などを求める（参：図一6）。 そ の操作結果に対する適応度を表ー1の方法で計算す る.もし適応度が 1.0 になるか、または世代数があ らかじめ設定した值に到達した場合には計算を終了 する。一方、それ以外の場合には、選択・交叉・突 然変異などの遺伝操作によって次世代の個体群を作 成し、再び同様の計算を繰り返す。

\section{5. 合流式下水道ポンプ操作の高度化}

ここでは上述の方法を用いて、表ー 1 に示した現 行型・改良型の比較を行い、雨水・污水ポンプの上 り高度な操作が可能になることを示す。

\section{（1）ファジィ制御ルールの学習過程とその結果}

本研究で用いた降雨パターンを図ー 4 に示す. 降 雨継続時間を 2 時間とし、最大降雨強度Rpを $10 \mathrm{~mm} / \mathrm{hr} \sim 40 \mathrm{~mm} / \mathrm{hr}$ として与えた。

$\mathrm{Rp}=30 \mathrm{~mm} / \mathrm{hr}$ に対する学習過程を図一 5 に示す. 学 習が進むにつれて、最大下水管水位は 5 m以下、最 大河川水位汢 3 m以下という条件を満たしつつ、污 濁排出量が次第に滅少していることがわかる．この

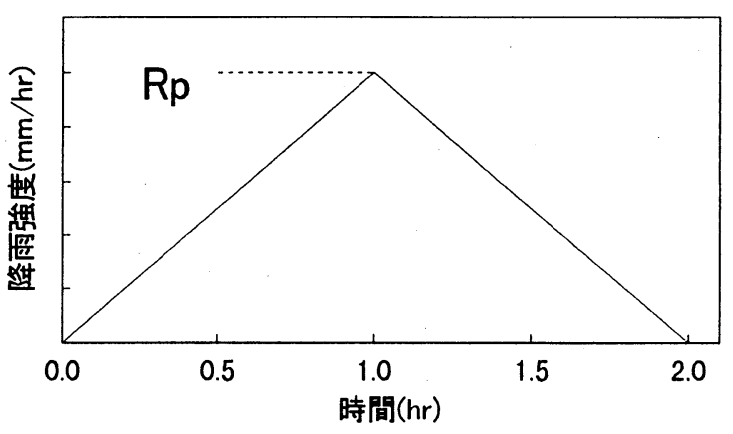

図ー4 計算に用いた降雨パターン

最大下水管水位 $(m)$

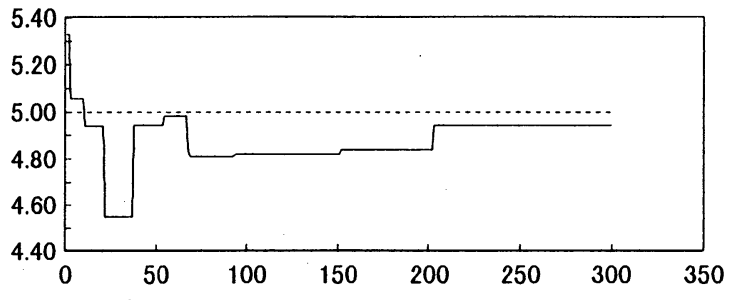

最大河川水位 $(\mathrm{m})$

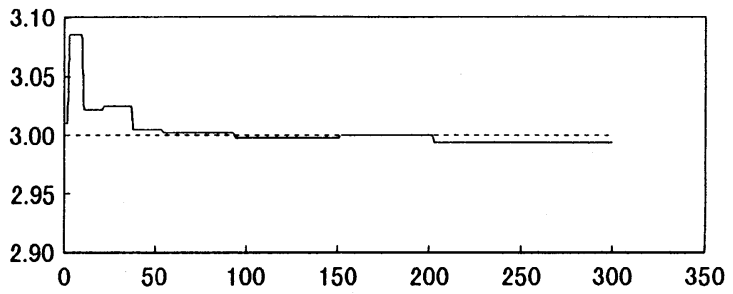

污濁抹出量 $\left(10^{5} \mathrm{~g}\right)$

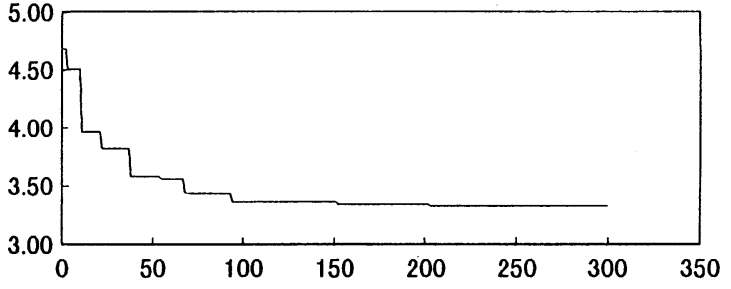

適応度

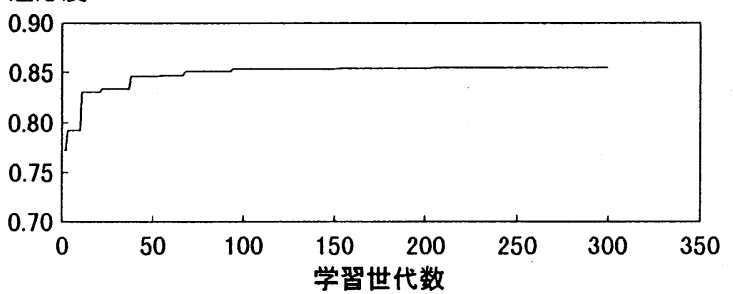

図－5 学習過程の一例 $(\mathrm{Rp}=30 \mathrm{~mm} / \mathrm{hr})$

例の場合、学習世代数が200を超えてからはそれほ ぞ顕著な適応度の上昇はみられないので、300世代 で計算を打ち切った。

つぎに上記の学習によりえられた制御ルールによ るポンプ操作結果を図ー6に示寸。降雨初期の高濃 度下水は污水ポンプにより、つぎのポンプ場または 下水処理場に送られている. そして下水水質がやや 低下し、下水管水位が上昇して $1 \mathrm{~m}$ を少し超えた段 階で、雨水ポンプが稼働し始めている。この場合、 污水ポンプは最大能力 $\left(0.67 \mathrm{~m}^{3} / \mathrm{sec}\right)$ で稼働してい 

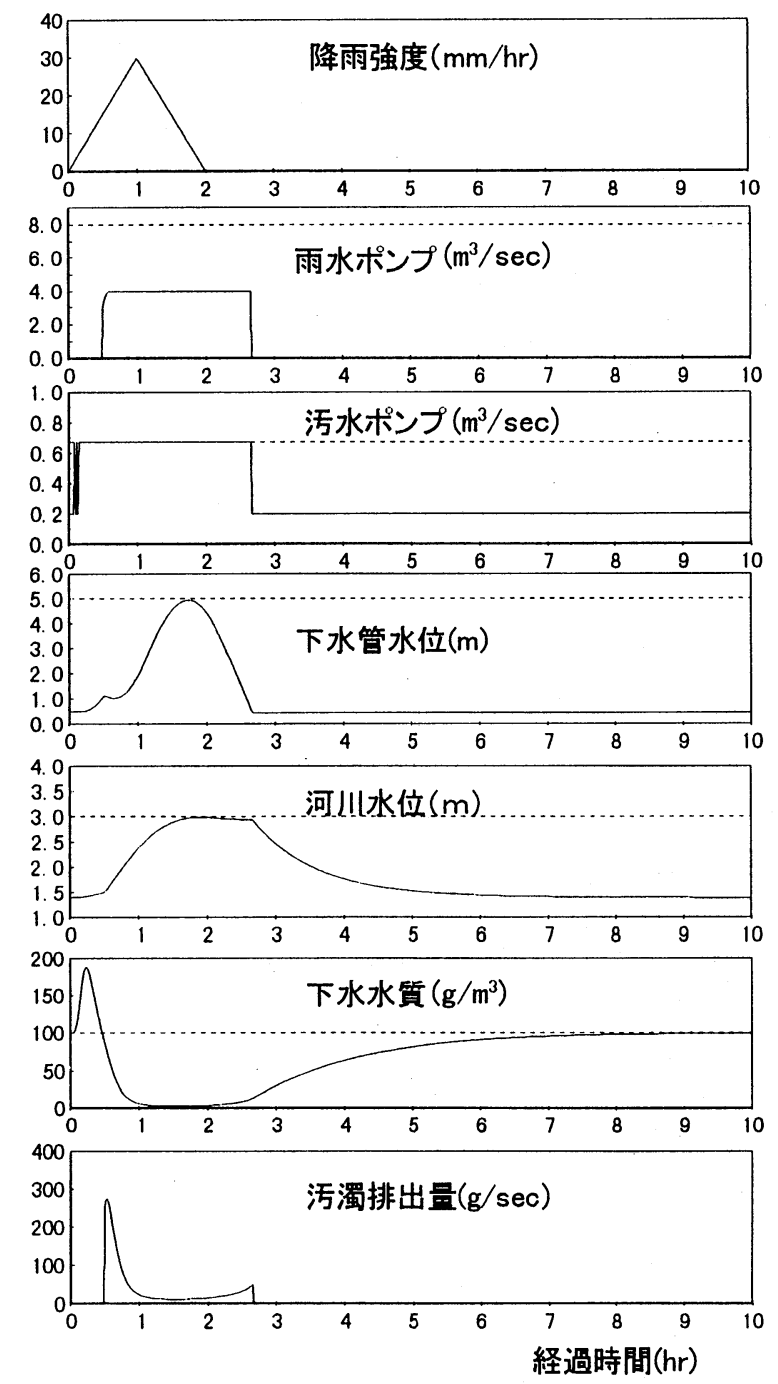

図ー6 ポンプ操作結果の一例（学習世代数=300）

るのに対し、雨水ポンプは最大能力 $\left(8 \mathrm{~m}^{3} / \mathrm{sec}\right)$ の半 分程度となっている.これはできるだけ雨水ポンプ による污濁排出を減少させるという目的にかなった 操作となっている.

一方、ある程度の時間経過の後には、下水水質が 低下しているので、下水管水位が $1 \mathrm{~m}$ 以下であって も、雨水ポンプによる排除が行われている。 そして 雨水流入が終了して下水管水位が低下してくると雨 水ポンプは停止し、污水流入量に相当する流量が污 水ポンプにより排出されて定常状態となる.

このような雨水・污水ポンプの操作方法は、現場 の監督者やオペレータへのヒアリング結果によく似 ている. 実際には下水水質は常時計測されていない のでポンプ操作時に参照することはできないが、初 期污濁を経験的に考慮しているためと推察できる. このような熟練才ペレータの操作方法に近い制御ルー ルが遺伝アルゴリズムで求められた点は注目に值す ると考える.

\section{（2）学習結果の汎用性}

ある降雨条件で学習した制御ルールがそれ以外の
降雨に対して、どの程度の汎用性をもつかについて 検討した結果を表一 2 に適応度で示している。 たと えばRp $=10 \mathrm{~mm} / \mathrm{hr}$ という学習条件（300世代）で得ら れた制御ルールを $\mathrm{Rp}=15,20, \ldots 40 \mathrm{~mm} / \mathrm{hr}$ という評価 条件に対して用いた場合、その適応度はそれぞれ、 $0.82,0.67, \ldots 、 0.51$ となり、それらの平均適応度 が0.67であったことを示している. 学習条件10〜 40mm/ hrを比較してみれば、より強い降雨による学 習結果のほうが平均適応度は高くなっていることが わかる。

一方、学習条件として複数の降雨、すなわち最大 降雨強度 $\mathrm{Rp}=10,20,30,40 \mathrm{~mm} / \mathrm{hr}$ を用いた場合も示し てある.この結果から明らかなように、単一の降雨 パターンによる学習よりも複数の降雨による学習結 果のほうが、汎用性はより高くなる。 もちろんこの 結果はある程度、定性的に予測できることでもある が、実用に際してはより広範囲の条件下で学習させ ることが必要といえる.

なお表中のイタリック表示は学習条件と評価条件 が同じ場合を示している.

表-2 学習条件と学習結果の汎用性

\begin{tabular}{|c|c|c|c|c|c|c|}
\hline \multirow{2}{*}{\multicolumn{2}{|c|}{$\begin{array}{c}\text { 最大降雨 } \\
\text { 強度 Rp } \\
(\mathrm{mm} / \mathrm{hr})\end{array}$}} & \multicolumn{5}{|c|}{ 学習条件 } \\
\hline & & \multirow{2}{*}{$\frac{10}{1.00}$} & \multirow{2}{*}{$\begin{array}{c}20 \\
1.00\end{array}$} & \multirow{2}{*}{$\begin{array}{c}30 \\
0.84\end{array}$} & \multirow{2}{*}{$\begin{array}{c}40 \\
0.87\end{array}$} & \multirow{2}{*}{$\begin{array}{r}10,20 \\
30,40 \\
1.00\end{array}$} \\
\hline \multirow{7}{*}{$\begin{array}{l}\text { 評 } \\
\text { 䅇 } \\
\text { 件 }\end{array}$} & 10 & & & & & \\
\hline & 15 & 0.82 & 0.95 & 0.87 & 0.86 & 0.87 \\
\hline & 20 & 0.67 & 0.92 & 0.86 & 0.79 & 0.90 \\
\hline & 25 & 0.59 & 0.76 & 0.86 & 0.85 & 0.88 \\
\hline & 30 & 0.54 & 0.55 & 0.85 & 0.78 & 0.86 \\
\hline & 35 & 0.52 & 0.45 & 0.64 & 0.70 & 0.71 \\
\hline & 40 & 0.51 & 0.40 & 0.56 & 0.74 & 0.71 \\
\hline \multicolumn{2}{|c|}{ 平均適応度 } & 0.67 & 0.72 & 0.79 & 0.80 & 0.85 \\
\hline
\end{tabular}

（3）ポンプ操作の高度化

表ー 1 に示すように降雨強度・下水管水位・河川 水位を入力情報として浸水制御を目的とした操作を 現行型とし、それに下水水質を加え、さらに污濁制 御をも考慮した操作を改良型として、両者を比較検 討した。ここでは学習条件として最大降雨強度 $\mathrm{Rp}=10,20,30,40 \mathrm{~mm} / \mathrm{hr}$ という複数の降雨パターンを 用い、300世代までの学習を行った。 その結果を図 ー 7に示す.

最大降雨強度Rpが30 mm/ hr以下の場合、現行型・ 改良型いずれも最大下水管水位は $5 \mathrm{~m}$ 以下、最大河 
最大下水管水位 $(\mathrm{m})$

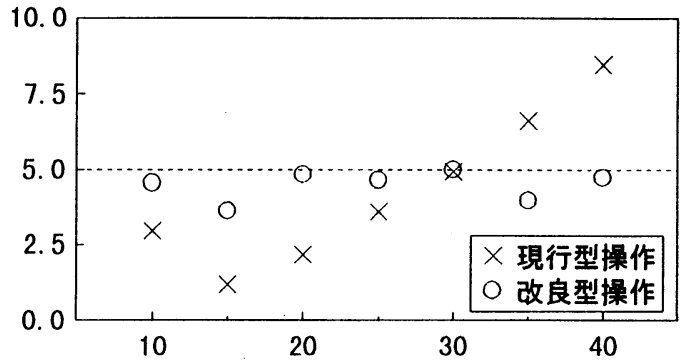

炚大河川水位 (m)

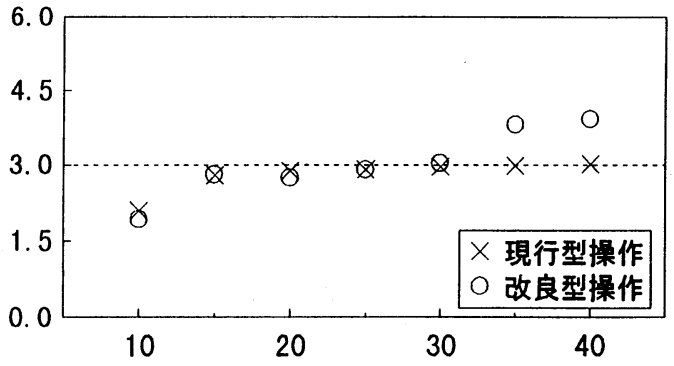

污濁排出早 $\left(10^{5} \mathrm{~g}\right)$

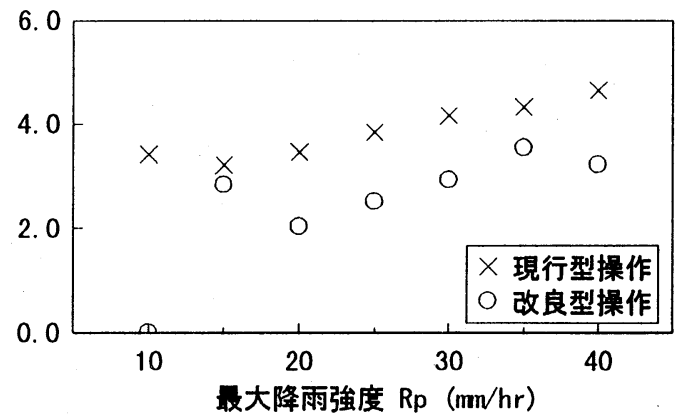

図一７現行型・改良型操作の比較

川水位は $3 \mathrm{~m}$ 以下という条件を満たしている。しか し、污濁排出量については改良型操作の方が少なく なっている。これは図－6の例からもわかるように、 雨水ポンプを抑制して降雨初期の高濃度下水を下水 管内にできるだけ貯留し、污水ポンプを最大にして 排除しているためである.

一方、Rpが $30 \mathrm{~mm} / \mathrm{hr}$ を超える場合についても、最 大下水管水位と污濁排出量に関しては改良型の方が 優れている. 改良型で最大河川水位がやや高くなっ ている理由の一つは、適応度に含まれる最大河川水 位の重み係数（表一 $1: \beta=0.2 ）$ が他の因子よりも 小さいので、河川水位を低下させるルールが強化さ れなかったためと考えられる. しかし、それ以外に も学習世代数、乱数系列等の影響もありうるので、 今後さらに検討が必要である.

以上の結果より、入力情報に下水水質を加え、適 応度に污濁排出量を加えて学習した制御ルールによ る改良型操作によって、より高度な雨水・污水ポン プ操作が可能となることがわかる。

\section{6. 結論}

本研究では合流式下水道ポンプ場における雨水・ 污水ポンプの操作にファジィ制御を適用し、その制
御ルールを遺伝アルゴリズムにより求める方法につ いて検討した．その結論を要約すれば、つぎのよう になる.

1）選択・交叉・突然変異で構成された遺伝アルゴ リズムにより、200〜300世代の計算でほぼ妥当 な制御ルールが自動的に作成できる.

2）学習結果の汎用性に関しては、より強い降雨、 より多様な降雨パターンを用いた方が汎用性は 高くなる.

3） ポンプ操作のための入力情報として降雨強度、 下水管水位、河川水位のみでなく、さらに下水 水質を加えることにより、浸水制御と污濁制御 を同時に行う、より高度な操作が可能となる.

謝辞 : 本研究は「大都市の水循環動態の分析に基づ 〈水質保全に関する研究」(環境庁、瀬戸内海研究 会議）の一部として実施された。ここに記して謝意 を表す。

\section{参考文献}

1) 八木俊策, 金子光美:ファジィ理論を用いた合流式下 水道のポンプ制御，下水道協会誌，第26巻303号, pp.71-80, 1989.

2) Yagi, S. : Application of Fuzzy Set Theory to the Computer Aided Control of Pumps in Combined Sewer Systems, Proc. 5th Int. Conf. on Urban Storm Drainage, pp. 1269-1274, 1990.

3) Yagi, S. : Fuzzy Control of Pumps in a Combined Sewer System and Its Effects on Flood and Pollution Management, Environmental Hydraulics, J. H. Lee \& Y. K. Cheung (eds), pp. 1443-1448, Balkema, 1991.

4）八木俊策：合流式下水道ポンプ場におけるファジィ 制御ルールの学習に対する遺伝アルゴリズムの適用, 第12回ファジィシステムシンポジウム講演論文集, pp.837-840, 1996.

5）八木俊策, 芝定孝 : 遺伝アルゴリズムを用いた合流式 下水道ポンプのファジィ制御，水工学論文集，No. 41,pp.167-172, 1997.

6) 八木俊策, 倉敷三樹男 : 遺伝アルゴリズムとファジィ 理論を用いた合流式下水道ポンプ操作手法の開発, 下水道協会誌論文集, Vol.34, No.413, pp.84-96, 1997.

7) Zadeh, L. A.: Outline of a new approach to the analysis of complex systems and decision processes, IEEE Trans. Systems, Man, and Cybernetics, SMC3(1), January, pp.28-44, 1973.

8) Sugeno, M.(ed.): Industrial Applications of Fuzzy Control, North-Holland, 1985.

9) 寺野寿郎他編 : 応用ファジィシステム入門,オーム社, 1989.

10) Davis, L. (ed.): Handbook of Genetic Algorithms, Van Nostrand Reinhold 1990, 嘉数他(訳) : 遺伝アルゴリズ ムハンドブック, 森北出版, 1994.

11) Karr, C.L.: Design of an Adaptive Fuzzy Logic Controller Using a Genetic Algorithm, Proc. of the 4th International Conference on Genetic Algorithms, pp.450-457, 1991.

12) 米澤保雄 : 遺伝的アルゴリズム, 森北出版, 1993. 